\title{
Synthesis of Iron-Doped Na- $\beta$ ”-Alumina + Yttria-Stabilized Zirconia Composite Electrolytes by a Vapor Phase Process
}

By

Leila Ghadbeigi ${ }^{\mathrm{a}}$, Alex Szendrei ${ }^{\mathrm{a}}$, Pablo Moreno ${ }^{\mathrm{b}}$, Taylor D. Sparks ${ }^{\mathrm{a}}$ and Anil V. Virkar, ${ }^{\mathrm{a},}$

\author{
${ }^{\mathrm{a} D e p a r t m e n t ~ o f ~ M a t e r i a l s ~ S c i e n c e ~ a n d ~ E n g i n e e r i n g ~}$ \\ 122 S. Central Campus Drive \\ University of Utah \\ Salt Lake City, UT 84112, USA
}

And

BCME Department

San Jose State University

San Jose, CA 95912

*Corresponding Author

Email: anil.virkar@utah.edu 


\begin{abstract}
Two phase samples containing $\sim 30$ vol. $\%$ of 3 mol. $\% \mathrm{Y}_{2} \mathrm{O}_{3}$-stabilized zirconia (TZ-3Y) and $\sim 70$ vol. $\%$ of $\alpha-\mathrm{Al}_{2} \mathrm{O}_{3}$ doped with 5 mol.\% $\mathrm{Fe}_{2} \mathrm{O}_{3}$ were fabricated by sintering powder compacts in air at $1450^{\circ} \mathrm{C}$. The added $\mathrm{Fe}_{2} \mathrm{O}_{3}$ was fully dissolved in $\mathrm{Al}_{2} \mathrm{O}_{3}$ as determined by X-ray diffraction. The two phase samples were packed in Na- $\beta$ "-alumina powder of nominal composition 8.85 wt. $\% \mathrm{Na}_{2} \mathrm{O}, 0.75$ wt. $\% \mathrm{Li}_{2} \mathrm{O}$ and balance $\mathrm{Al}_{2} \mathrm{O}_{3}$ and heat treated in air at $1250^{\circ} \mathrm{C}$ for 20 h. The samples were sectioned, polished and examined by X-ray diffraction, optical microscopy and scanning electron microscopy. The as-sintered samples were $\sim 97 \%$ of theoretical density with an approximate grain size of $\sim 0.8$ microns. In the samples packed in Na- $\beta$ "-alumina powder and heat treated in air, Fe-doped $\alpha-\mathrm{Al}_{2} \mathrm{O}_{3}$ converted into Fe-doped Na- $\beta$ "-alumina. A sample of 2.35 $\mathrm{mm}$ in thickness could be fully converted into iron-doped Na- $\beta$ "-alumina in 17 hours at $1450^{\circ} \mathrm{C}$. Ionic conductivity was measured by electrochemical impedance spectroscopy (EIS) over a temperature range from $197^{\circ} \mathrm{C}$ to $485^{\circ} \mathrm{C}$. The bulk conductivity of the converted sample exhibited Arrhenius behavior with an activation energy of $0.20 \mathrm{eV}$ and a pre-exponential factor of $420 \mathrm{Scm}^{-1} \mathrm{~K}$.
\end{abstract}

Key Words: Na- $\beta$ "-alumina, zirconia, vapor phase process, sodium-sulfur batteries. 


\section{Introduction}

$\mathrm{Na}-\beta$ "-alumina has a nominal composition of $\mathrm{Na}_{2} \mathrm{O} \cdot \sim 6 \mathrm{Al}_{2} \mathrm{O}_{3}$ (with a small amount of $\mathrm{Li}_{2} \mathrm{O}$ or $\mathrm{MgO}$ added in the conventional sintering process) and a rhombhohedral structure which can be indexed as a hexagonal unit cell with $\mathrm{a}=6.06 \AA$ and $\mathrm{c}=33.74 \AA[1,2]$. Three Al-O spinel blocks are stacked one on top of other rotated through $120^{\circ}$. The spinel blocks are joined by bridging oxygen ions [2]. Sodium ions reside in the c-planes separating the spinel blocks and are highly mobile in the conduction plane. Thus, Na- $\beta$ "-alumina is a highly anisotropic ionic conductor with virtually no ionic conductivity perpendicular to the c-direction. In most applications, therefore, Na- $\beta$ "-alumina is used in a polycrystalline form. Polycrystalline samples with random orientation of grains exhibit isotropic conductivity which is typically about half that of single crystals in the conduction planes. In addition, there is usually some resistance to the transport of sodium ions across grain boundaries, which decreases with increasing temperature. Thus, the ionic conductivity of Na- $\beta$ "-alumina is an inverse function of its grain size. For a sample of about 4 to 5 microns in grain size, the ionic conductivity of $\mathrm{Na}-\beta$ "-alumina at $300^{\circ} \mathrm{C}$ is about 0.2 to $0.33 \mathrm{Scm}^{-1}$ making it one of most highly conducting solid electrolytes. Its high ionic conductivity, excellent chemical stability and highly refractory nature makes it an ideal candidate for high temperature electrochemical devices based on sodium ion conduction. The largest application of Na- $\beta$ "-alumina as a solid electrolyte is in sodium-sulfur batteries and sodiummetal chloride batteries $[3,4]$. NGK in Japan is the largest manufacturer of Na-S batteries which markets them under the name NAS batteries. In the NAS battery Na- $\beta$ "-alumina is used as a one 
end closed tube of about $50 \mathrm{~mm}$ diameter, $2 \mathrm{~mm}$ thickness and about $50 \mathrm{~cm}$ length. The actual battery module is rated at $50 \mathrm{~kW}$ with a discharge time of $8 \mathrm{~h}$ corresponding to a storage capacity of $400 \mathrm{kWh}$. This forms the basic building block of modular batteries. Batteries as large as 64 MWh have been demonstrated. Currently, some units have been in operation for over 10 years and are used for load-leveling applications. Sodium-metal chloride (typically nickel chloride) batteries are called ZEBRA batteries [4]. These are also fabricated in several $\mathrm{kWh}$ sizes and are being explored for stationary as well as transportation (locomotive) applications.

The conventional process for the fabrication of $\mathrm{Na}-\beta$ "-alumina involves the following steps [5]: Powders of $\mathrm{Na}_{2} \mathrm{CO}_{3}$ and $\mathrm{Al}_{2} \mathrm{O}_{3}$ are mixed in an appropriate ratio to form a mixture corresponding to $\sim 8-9$ wt. $\% \mathrm{Na}_{2} \mathrm{O}$ and balance $\mathrm{Al}_{2} \mathrm{O}_{3}$. Studies have shown that if such a binary mixture is heated to a high temperature $\left(>1250^{\circ} \mathrm{C}\right)$, it leads to the formation of $\mathrm{Na}_{2} \mathrm{O} \cdot 11 \mathrm{Al}_{2} \mathrm{O}_{3}$ and $\mathrm{NaAlO}_{2}$. The former structure is called Na- $\beta$-alumina. It is also a sodium ion conductor but with ionic conductivity one fifth that of Na- $\beta$ "-alumina. It has been long known that a small amount of $\mathrm{Li}_{2} \mathrm{O}$ or $\mathrm{MgO}$ must be added to form Na- $\beta$ "-alumina by conventional sintering in air. The added lithium or magnesium enters the spinel blocks and partially substitutes for aluminum. $\mathrm{Al}$ is $3+$ while $\mathrm{Li}$ is $1+$ and $\mathrm{Mg}$ is $2+$. Thus, for charge compensation an additional amount of sodium is introduced into the conduction plane. With lithium as the stabilizer the typical composition is 8.85 wt.\% $\mathrm{Na}_{2} \mathrm{O}, 0.75$ wt. $\% \mathrm{Li}_{2} \mathrm{O}$ and 90.4 wt.\% $\mathrm{Al}_{2} \mathrm{O}_{3}$ [5]. Densification in the conventional process involves a transient liquid phase mechanism. There is a eutectic in the $\mathrm{Na}_{2} \mathrm{O}-\mathrm{Al}_{2} \mathrm{O}_{3}$ system between $\mathrm{NaAlO}_{2}$ and $\mathrm{Na}_{2} \mathrm{O} .11 \mathrm{Al}_{2} \mathrm{O}_{3}$ which occurs at $\sim 1580^{\circ} \mathrm{C}$. For densification to occur the sample is heated to a temperature slightly above the eutectic temperature. Densification occurs rapidly (within seconds or minutes). This is also accompanied by the reaction of $\mathrm{NaAlO}_{2}$ 
and $\mathrm{Na}_{2} \mathrm{O} .11 \mathrm{Al}_{2} \mathrm{O}_{3}$ (and also with added $\mathrm{Li}_{2} \mathrm{O}$ or $\mathrm{MgO}$ ) to form the desired $\mathrm{Na}-\beta$ "-alumina phase. This is accompanied by exaggerated grain growth causing a duplex microstructure which is deleterious to its strength. Also the vapor pressure of $\mathrm{Na}_{2} \mathrm{O}$ is relatively high and considerable loss of $\mathrm{Na}_{2} \mathrm{O}$ can occur through the vapor phase. Thus sintering of $\mathrm{Na}-\beta$ "-alumina is achieved by encapsulating the samples in platinum or $\mathrm{MgO}$ containers. Significant cost is associated with the use of either type of container. In order to minimize the grain growth and also allow for full conversion to Na- $\beta$ "-alumina to occur by the reaction

$$
\mathrm{Na}-\beta \text {-alumina }+\mathrm{NaAlO}_{2} \rightarrow \mathrm{Na}-\beta \text { ”-alumina }
$$

the furnace temperature is rapidly lowered to about $1450^{\circ} \mathrm{C}$ after sintering for a few minutes above $1580^{\circ} \mathrm{C}$. The samples are heat treated at $1450^{\circ} \mathrm{C}$, while still under encapsulation, for 1 to 2 $\mathrm{h}$ before slow cooling to room temperature. Using such a process it is possible to obtain nearly $\sim 100 \% \mathrm{Na}-\beta$ "-alumina. However, a thin film of $\mathrm{NaAlO}_{2}$ usually remains trapped along the grain boundaries. As a result Na- $\beta$ "-alumina made by the conventional process is attacked by atmospheric moisture and carbon dioxide. Reaction of grain boundary $\mathrm{NaAlO}_{2}$ with moisture involves its dissolution. Reaction with $\mathrm{CO}_{2}$ involves the formation of $\mathrm{Na}_{2} \mathrm{CO}_{3}$. In either case cracks and delaminations occur along the grain boundaries. Thus, Na- $\beta$ "-alumina made by the conventional process is stored in desiccators and heated to about $\sim 600^{\circ} \mathrm{C}$ before use in electrochemical devices.

A novel vapor phase process was developed in which a two phase composite of $\alpha-\mathrm{Al}_{2} \mathrm{O}_{3}$ and an oxygen ion conductor, such as yttria-stabilized zirconia (YSZ), is made by conventional sintering 
powder compacts such that both phases are contiguous [6]. In the subsequent step the sintered samples are packed in Na- $\beta$ "-alumina powder and heat treated at a temperature between about $1150^{\circ} \mathrm{C}$ and $1450^{\circ} \mathrm{C}$ for several hours. $\mathrm{Na}_{2} \mathrm{O}$ from the packing powder is incorporated into $\alpha$ $\mathrm{Al}_{2} \mathrm{O}_{3}$ by the reaction

$$
\mathrm{Na}_{2} \mathrm{O}+\sim 6 \mathrm{Al}_{2} \mathrm{O}_{3} \rightarrow \mathrm{Na}_{2} \mathrm{O} . \sim 6 \mathrm{Al}_{2} \mathrm{O}_{3}
$$

The incorporation of $\mathrm{Na}_{2} \mathrm{O}$ occurs by coupled diffusion of $2 \mathrm{Na}^{+}$through the formed $\mathrm{Na}-\beta$ "alumina and of $\mathrm{O}^{2-}$ through the YSZ. Since the diffusion of $\mathrm{O}^{2-}$ is rapid through $\mathrm{YSZ}$ and the diffusion of $2 \mathrm{Na}^{+}$is rapid through Na- $\beta$ "-alumina, rapid conversion of $\alpha-\mathrm{Al}_{2} \mathrm{O}_{3}$ into Na- $\beta$ "alumina occurs. The resulting material is a two phase mixture of Na- $\beta$ "-alumina and YSZ, both forming contiguous phases. The overall kinetics of conversion involves one diffusional step (coupled diffusion of $2 \mathrm{Na}^{+}$through $\mathrm{Na}-\beta$ "-alumina and of $\mathrm{O}^{2-}$ through YSZ) and two interface steps. One of the interface steps is at the gas/solid interface where $\mathrm{Na}_{2} \mathrm{O}$ from the gas phase is incorporated at the Na- $\beta$ "-alumina/YSZ/gas phase three phase boundaries (TPBs) with $2 \mathrm{Na}^{+}$ entering Na- $\beta$ "-alumina and $\mathrm{O}^{2-}$ entering YSZ. The second interface step occurs at the reaction front, the Na- $\beta$ "-alumina $+\mathrm{YSZ} / \alpha-\mathrm{Al}_{2} \mathrm{O}_{3}+\mathrm{YSZ}$ interface, where reaction (2) occurs. Figure 1 shows a schematic of the transport processes and reaction occurring during vapor phase conversion [7].

There are many ions which in principle can partially substitute for $\mathrm{Al}^{3+}$ in the spinel structure. The valence of the substituting ion and its size relative to the size of $\mathrm{Al}^{3+}$ are expected to be the primary factors which determine if a substitution is possible. The phase diagram between $\mathrm{Fe}_{2} \mathrm{O}_{3}$ 
and $\mathrm{Al}_{2} \mathrm{O}_{3}$ shows that the solubility of $\mathrm{Fe}_{2} \mathrm{O}_{3}$ in $\mathrm{Al}_{2} \mathrm{O}_{3}$ is $\sim 13.5 \mathrm{~mol} \% \%$ at $1400^{\circ} \mathrm{C}$ [8]. In the system $\mathrm{Na}_{2} \mathrm{O}-\mathrm{Fe}_{2} \mathrm{O}_{3}$, a $\mathrm{Na}-\beta-\mathrm{Fe}_{2} \mathrm{O}_{3}$ (analogous to $\mathrm{Na}-\beta$-alumina) is known to be stable above $680^{\circ} \mathrm{C}$, but no $\beta$ "'-phase has been reported [8]. However, as $\mathrm{Fe}_{2} \mathrm{O}_{3}$ exhibits some solubility in $\mathrm{Al}_{2} \mathrm{O}_{3}$, it may be possible to form iron-doped Na- $\beta$ "-alumina. The objective of this work was to determine if iron-doped Na- $\beta$ "-alumina can be formed by the vapor phase process by exposing a composite of $\mathrm{YSZ}$ and Fe-doped $\mathrm{Al}_{2} \mathrm{O}_{3}$ to $\mathrm{Na}_{2} \mathrm{O}$ vapor.

\section{Experimental Procedure}

A powder mixture containing 95 mol. $\% \alpha-\mathrm{Al}_{2} \mathrm{O}_{3}\left(\mathrm{CR}-30\right.$ Baikowski) +5 mol. $\% \mathrm{Fe}_{2} \mathrm{O}_{3}$ and 3 mol.\% $\mathrm{Y}_{2} \mathrm{O}_{3}$-stabilized $\mathrm{ZrO}_{2}$ (TZ-3Y, Tosoh) was made with 70 vol.\% $\alpha-\mathrm{Al}_{2} \mathrm{O}_{3}+\mathrm{Fe}_{2} \mathrm{O}_{3}$ and 30 vol.\% TZ-3Y. According to the $\mathrm{Al}_{2} \mathrm{O}_{3}-\mathrm{Fe}_{2} \mathrm{O}_{3}$ phase diagram, the maximum solubility of $\mathrm{Fe}_{2} \mathrm{O}_{3}$ in $\mathrm{Al}_{2} \mathrm{O}_{3}$ is $\sim 13.5 \mathrm{~mol} \%$ at $1400^{\circ} \mathrm{C}$ [9]. Thus, 5 mol. $\% \mathrm{Fe}_{2} \mathrm{O}_{3}$, if completely dissolved in $\alpha$ $\mathrm{Al}_{2} \mathrm{O}_{3}$, is expected to be well within the solubility range. The powder mixture was ball milled in Fritsch Pulversette planetary mill at $300 \mathrm{rpm}$ for $3 \mathrm{~h}$. Several discs were prepared by die-pressing using a uniaxial press under a pressure of $97 \mathrm{MPa}$. The discs were then sintered in air at $1450^{\circ} \mathrm{C}$ for $3 \mathrm{~h}$ in a Lindberg Blue CC5926PCOMC-1 furnace. The typical thickness of the discs was between 2 and $3 \mathrm{~mm}$. Densities of the sintered discs were measured by the fluid immersion method using water. The discs were then placed in an alumina crucible, loosely packed in Na- $\beta$ "alumina powder containing $\sim 8.85$ wt. $\% \mathrm{Na}_{2} \mathrm{O}, \sim 0.75$ wt. $\% \mathrm{Li}_{2} \mathrm{O}$ and balance $\mathrm{Al}_{2} \mathrm{O}_{3}$, covered with a lid and heat-treated at $1250^{\circ} \mathrm{C}$ in air for $20 \mathrm{~h}$. The expectation was that this treatment would 
convert Fe-doped $\mathrm{Al}_{2} \mathrm{O}_{3}+$ TZ-3Y two phase material into Fe-doped Na- $\beta$ "-alumina + TZ-3Y two phase material by the vapor phase process involving coupled diffusion of $\mathrm{Na}^{+}$through $\mathrm{Fe}-$ doped Na- $\beta$ "-alumina and of $\mathrm{O}^{2-}$ through TZ-3Y. Baseline samples containing $\sim 70$ vol. $\% \mathrm{Al}_{2} \mathrm{O}_{3}$ and $\sim 30$ vol. $\%$ TZ-3Y were also fabricated and subjected to the conversion treatment by packing in Na- $\beta$ "-alumina powder.

After conversion the samples were cross-sectioned, coarsely polished and thermally etched in air at $1250^{\circ} \mathrm{C}$ for 15 minutes. A NOVA NANOSEM 600 scanning electron microscope was used to measure the grain size. An Olympus BH2-UMA Nomarsky interference microscope was used to measure the conversion thickness. X-ray diffraction patterns were obtained using $\mathrm{CuK} \alpha$ radiation on a Phillips X'Pert X-ray diffractometer to determine the phases present in the assintered and the converted samples. Lattice parameters were obtained using GSAS software with Rietveld refinement. The composition of the $\mathrm{Al}_{2} \mathrm{O}_{3}-\mathrm{Fe}_{2} \mathrm{O}_{3}$ solid solution was estimated from a linear fit to the lattice parameters assuming Vegard's law. One sample was heat treated at $1450^{\circ} \mathrm{C}$ packed in Na- $\beta$ "-alumina powder for $17 \mathrm{~h}$. The objective was to fully convert the sample for the measurement of conductivity by EIS.

Platinum paste (Heraeus) electrodes were applied symmetrically on both surfaces of the disc and fired at $800^{\circ} \mathrm{C}$ for $0.5 \mathrm{~h}$. The electrode area was $1.27 \mathrm{~cm}^{2}$ and the sample thickness was $2.35 \mathrm{~mm}$. EIS was performed with a Solartron electrochemical interface (SI 1287) and impedance/gainphase analyzer (SI 1260) using a 4-probe method. The range of frequencies tested was $100 \mathrm{~Hz}$ to $1 \mathrm{MHz}$, with a $4 \mathrm{mV}$ amplitude. The temperature of the sample was varied from $197^{\circ} \mathrm{C}$ to $485^{\circ} \mathrm{C}$ using a Barnstead Thermolyne 2100 tube furnace. The temperature of the sample was monitored 
with a Omega K-type thermocouple read from a Keithley 2000 meter. The high frequency intercept was obtained from the Nyquist plots, which was attributed to the bulk resistance of the sample.

\section{Results and Discussion}

X-ray diffraction patterns were refined by the Rietveld refinement method using XPGUI GSAS software. Figures 2(a), 2(b), 2(c) and 2(d) are respectively XRD patterns of sintered $\alpha-\mathrm{Al}_{2} \mathrm{O}_{3}+$ TZ-3Y, converted Na- $\beta$ "-alumina + TZ-3Y, sintered Fe-doped $\alpha-\mathrm{Al}_{2} \mathrm{O}_{3}+\mathrm{TZ}-3 \mathrm{Y}$ and converted Fe-doped Na- $\beta$ "-alumina + TZ-3Y. Lattice parameters determined by refining XRD patterns are listed in Table 1 . As seen in the table, the Fe-doped $\alpha-\mathrm{Al}_{2} \mathrm{O}_{3}$ has slightly larger lattice parameters than the undoped $\alpha-\mathrm{Al}_{2} \mathrm{O}_{3}$ consistent with the higher ionic radius of $\mathrm{Fe}^{3+}$ compared to $\mathrm{Al}^{3+}$. For Fe-doped $\alpha-\mathrm{Al}_{2} \mathrm{O}_{3}$, lattice parameters were also estimated using Vegard's law assuming the lattice parameters of pure hematite as $a=b=5.038 \AA$ and $c=13.772 \AA$. A comparison of the lattice parameters determined by refinement and Vegard's law are in good agreement. A calculation of the d-spacing for the (124) reflection yielded a value of $1.407 \AA$. Using the standard curve for this reflection constructed by Muan and Lee [9] the composition was estimated as $\mathrm{Fe}_{0.1} \mathrm{Al}_{1.9} \mathrm{O}_{3}$. The only phases observed in the Fe-doped $\alpha-\mathrm{Al}_{2} \mathrm{O}_{3}+\mathrm{TZ}-3 \mathrm{Y}$ corresponded to the alumina structure and zirconia indicating that hematite was completely dissolved in $\alpha-\mathrm{Al}_{2} \mathrm{O}_{3}$. Based on the reported phase diagram, the selected composition is well within the solubility limit [9]. In all patterns, the TZ-3Y strongest peak (indexed as a pseudo- 
cubic phase) is (111) at $2 \theta=30^{\circ}$ and the second strongest peak is (200) at $2 \theta=34.77^{\circ}$. The (220) peak occurs at $2 \theta=50^{\circ}$. These peaks are seen in all four patterns. Additionally the two peaks at $2 \theta \sim 73.5^{\circ}$ correspond to (004) and (400) and the tetragonal structure of TZ-3Y is clearly evident. The peak at $2 \theta=34.77^{\circ}$ is much stronger in the as-sintered samples as compared to the converted samples. This is because the (104) peak of $\alpha-\mathrm{Al}_{2} \mathrm{O}_{3}$ also occurs at $2 \theta=34.77^{\circ}$. The sharp decrease in the intensity of the peak at $2 \theta=34.77^{\circ}$ in the converted samples is due to the conversion of $\alpha-\mathrm{Al}_{2} \mathrm{O}_{3}$ into Na- $\beta$ "-alumina. Note also that the peaks at $2 \theta=25^{\circ}$ and $2 \theta=43^{\circ}$ present in the unconverted samples are reduced in intensity in the converted samples, consistent with a reaction of $\alpha-\mathrm{Al}_{2} \mathrm{O}_{3}$ with $\mathrm{Na}_{2} \mathrm{O}$ to form $\mathrm{Na}-\beta$ "-alumina. Finally, the presence of a series of closely spaced peaks in the range $2 \theta=35^{\circ}$ and $2 \theta=42^{\circ}$ in the converted samples is in accord with the formation of the Na- $\beta$ "-alumina phase. Also note that the peak at $2 \theta=58^{\circ}$ in the assintered samples has nearly disappeared in the converted samples. This indicates that in both Fedoped and undoped samples, conversion to Na- $\beta$ "-alumina occurred within the conversion thickness. There was some $\alpha$-alumina left in the sample indicating that there was some noncontiguity due to incomplete mixing of the powders. The lattice parameters of Na- $\beta$ "-alumina are $\mathrm{a}=\mathrm{b}=5.606 \AA$ and $\mathrm{c}=33.737 \AA$. These lattice parameters are on a hexagonal basis. The crystal structure of Na- $\beta$ "-alumina is rhombohedral. Thus, $-\mathrm{h}+\mathrm{k}+\mathrm{l}=3 \mathrm{n}$ where $\mathrm{n}$ is an integer, when indexed as a hexagonal unit cell.

A small piece of the sample converted at $1450^{\circ} \mathrm{C}$ for $17 \mathrm{~h}$ was cut through the thickness with a diamond blade saw. Visual examination showed no discontinuities on the cut surface, indicating that the entire sample was converted and it was deemed suitable for the measurement of conductivity by EIS. Some alumina was still present in the converted region, as indicated in the 
XRD of the sample. This was again attributed to incomplete mixing of powders and thus the possible presence of non-contiguous regions of alumina and/or zirconia. The regions of alumina that are non-contiguous are not expected to convert to Na- $\beta$ "-alumina.

Figure 3(a) is an SEM image of an as-sintered sample of Fe-doped $\alpha-\mathrm{Al}_{2} \mathrm{O}_{3}+$ TZ-3Y. The average grain size (of both phases) is about $\sim 0.8 \mu \mathrm{m}$ as measured by the linear intercept method. The slightly darker grains are of $\alpha-\mathrm{Al}_{2} \mathrm{O}_{3}$. Figure 3(b) is an SEM image of the converted sample containing Fe-doped Na- $\beta$ "-alumina and TZ-3Y. The dark regions are of Na- $\beta$ "-alumina and the light regions are of TZ-3Y. The conversion of $\alpha-\mathrm{Al}_{2} \mathrm{O}_{3}$ into Na- $\beta$ "-alumina involves the incorporation of $\mathrm{Na}_{2} \mathrm{O}$ per every $\sim 6 \mathrm{Al}_{2} \mathrm{O}_{3}$ thus leading to an increase in mass. Also, the density of $\alpha-\mathrm{Al}_{2} \mathrm{O}_{3}$ is $3.99 \mathrm{gml}^{-1}$ while that of $\mathrm{Na}-\beta$ "-alumina is $3.28 \mathrm{gml}^{-1}$. Thus, conversion of $\alpha-\mathrm{Al}_{2} \mathrm{O}_{3}$ into Na- $\beta$ "-alumina also leads to an increase in volume. Since the mass and the volume of TZ$3 \mathrm{Y}$ are unchanged, the volume fraction of Na- $\beta$ "-alumina is greater in the converted samples as compared to the volume fraction of $\alpha-\mathrm{Al}_{2} \mathrm{O}_{3}$ in the as-sintered samples. This is clearly seen in Figure 3(b) in which the volume fraction of the dark phase (Na- $\beta$ "-alumina) is greater than that of $\alpha-\mathrm{Al}_{2} \mathrm{O}_{3}$ in the as-sintered sample. Note that the TZ-3Y phase even in the converted sample must be contiguous as required for coupled transport to occur. Its appears non-contiguous in the two-dimensional image as its amount is relatively small ( $\sim 25$ vol.\%). Figure 3(c) is an optical micrograph under Nomarsky interference contrast showing the boundary between the converted and the unconverted regions. The conversion thickness was about 200 microns. In the work of Parthasarathy and Virkar [7], the measured thickness was about 500 microns. It appears that the kinetics of conversion in the Fe-doped material is slower. The reason for the slower conversion 
kinetics is not known at the present time. It is possible that inhomogeneous mixing of powders may be a contributing factor.

The measured density of the $\mathrm{Fe}_{0.1} \mathrm{Al}_{1.9} \mathrm{O}_{3} / \mathrm{TZ}-3 \mathrm{Y}$ samples was $\sim 97 \%$ of the theoretical density, the latter determined using a rule of mixtures with the lattice parameters estimated from the XRD patterns. EIS spectra of the converted sample converted at $1450^{\circ} \mathrm{C}$ for $17 \mathrm{~h}$ are shown in Figure 4. Figure 4(a) shows the EIS spectra at $197^{\circ} \mathrm{C}$ with the close up of the high frequency region shown in Figure 4(b). An approximate value of the net bulk ohmic resistance of the sample corresponds to the high frequency intercept on the Z' (real) axis. Figure 4(c) is an EIS spectrum at $290^{\circ} \mathrm{C}$ of the converted sample. The point corresponding to the highest frequency of $1 \mathrm{MHz}$ is slightly below the axis indicating the presence of an inductive effect due to lead wires. This suggests that even with a 4-probe measurement, possible inductive contribution was not completely eliminated [10]. The net bulk ohmic resistance calculated by interpolation is $16.3 \Omega$. A close up of the high frequency region of the spectrum is shown in Figure 4(d).

The converted sample contains two contiguous ionic conductors; TZ-3Y which is an $\mathrm{O}^{2-}$ ion conductor and Na- $\beta$ "-alumina, which is a $\mathrm{Na}^{+}$ion conductor. Figure 5 is a plot of the natural logarithm of the product of the measured conductivity, $\sigma$, and the absolute temperature, $T$, vs. the inverse of the absolute temperature. The conductivity was estimated from the net bulk resistance values determined by EIS over the temperature range $197^{\circ} \mathrm{C}$ to $485^{\circ} \mathrm{C}$. The plot is linear with a coefficient of correlation of 0.9986 . The conductivity can be described by an equation of the form 


$$
\sigma T=\sigma_{o} \exp \left(-\frac{E}{k_{B} T}\right)
$$

where $\sigma_{o}$ is a pre-exponential factor $\mathrm{Scm}^{-1} \mathrm{~K}^{-1}, E$ is the activation energy, and $k_{B}$ is the Boltzmann constant. The estimated activation energy is $0.20 \mathrm{eV}$ with a pre-exponential factor of $420 \mathrm{Scm}^{-1} \mathrm{~K}$.

At $350^{\circ} \mathrm{C}$, the measured conductivity from Figure 5 is $0.0163 \mathrm{Scm}^{-1}$. Over the temperature range the measurements were made in the present study, oxygen ion conductivity of TZ-3Y is expected to be much lower than that of Na- $\beta$ "-alumina. For example, the reported ionic conductivity of TZ-3Y [11] at $350^{\circ} \mathrm{C}$ is $\sim 1.43 \times 10^{-5} \mathrm{Scm}^{-1}$. The measured conductivity in the present experiments is more than 3 orders of magnitude greater than that of TZ-3Y. Thus, the measured conductivity in the present work is attributed exclusively to sodium ion conduction through the Na- $\beta$ "-alumina phase. In an earlier study by one of the authors, conductivity was measured on Na- $\beta$ "-alumina samples of two grain sizes; $\sim 2$ microns and $\sim 100$ microns made by the conventional sintering process [12]. The conductivity was higher in the coarse-grained sample. Lower conductivity of fine-grained samples was attributed to the resistance associated with transport across grain boundaries. Both fine-grained and coarse-grained samples exhibited some curvature in the Arrhenius plots. From the grain size dependence of conductivity, contribution of the grain boundary conductance as a function of temperature was estimated. It was observed that grain boundaries are less conductive than grains and also exhibit greater activation energy $\left(\sim 32.09 \mathrm{kJmol}^{-1}\right.$ or $\left.\sim 0.33 \mathrm{eV}\right)$. For the coarse-grained $(\sim 100 \mu \mathrm{m})$ samples, the measured activation energy varied between $\sim 0.16 \mathrm{eV}$ to $\sim 0.183 \mathrm{eV}$ over the temperature range 
measurements were made. This variation in activation energy which resulted in curvature in the Arrhenius plots was attributed to the grain boundary contribution to the total ionic resistance.

In the present work no curvature is observed in the Arrhenius plot and the measured activation energy is $\sim 0.2 \mathrm{eV}$. Figure 4(b) and Figure 4(d) show that the high frequency part appears to be semi-circular representing grain-grain boundary contributions. As the highest frequency at which measurements were made was $1 \mathrm{MHz}$, it is expected that that grain boundaries are shorted. The corresponding high frequency intercept thus should correspond to the grain resistance. The measured resistance at $350^{\circ} \mathrm{C}$ is about 30 times larger than expected for a high quality Na- $\beta$ "alumina. Higher resistivity (lower conductivity) of the samples in the present work may be attributed to a number of factors. (1) The sample was two phase with 25 vol.\% TZ-3Y. (2) Powder mixture was inhomogeneous. As a result, there was some unconverted $\alpha$-alumina left in the sample. These two factors mean the volume percent of Na- $\beta$ "-alumina was less than about 70\%. (3) Sample composition was not optimized. It may be necessary to conduct experiments using packing powders containing higher amounts of $\mathrm{Na}_{2} \mathrm{O}$. (4) In $\mathrm{Na}-\beta$ "-alumina processed using the conventional process, some $\mathrm{Li}_{2} \mathrm{O}$ is added. $\mathrm{Li}^{+}$partially substitutes for $\mathrm{Al}^{3+}$ in the spinel blocks, thus increasing the $\mathrm{Na}^{+}$concentration in the conduction plane. In the present work, there was some $\mathrm{Li}_{2} \mathrm{O}$ in the packing powder. However, it is not expected to enter the Na- $\beta$ "-alumina phase formed by the vapor phase process since diffusivity of $\mathrm{Li}^{+}$in the spinel blocks is very low. In future work, we will add either $\mathrm{Li}_{2} \mathrm{O}$ or $\mathrm{MgO}$ directly into the initial powder mixture. The added $\mathrm{Li}_{2} \mathrm{O}$ should form some $\mathrm{LiAl}_{5} \mathrm{O}_{8}$ spinel and the added $\mathrm{MgO}$ should form some $\mathrm{MgAl}_{2} \mathrm{O}_{4}$ phase (and some may be incorporated into zirconia). During the vapor phase process, $\mathrm{Li}_{2} \mathrm{O}$ or $\mathrm{MgO}$ will likely be incorporated into the spinel blocks of Na- $\beta$ "-alumina since the diffusion 
distance is relatively small - on the order of a few microns. Also, in order to increase the ionic conductivity, it may be necessary to increase the grain size by sintering the samples at higher temperatures.

\section{Summary}

In the present work two phase samples of Fe-doped $\alpha$-alumina + TZ-3Y were fabricated by sintering powder compacts in air. $\mathrm{Fe}_{2} \mathrm{O}_{3}$ was completely dissolved in $\alpha-\mathrm{Al}_{2} \mathrm{O}_{3}$. Vapor phase conversion to a two phase mixture containing Fe-doped Na- $\beta$ "-alumina + TZ-3Y was achieved by heat treating Fe-doped $\alpha$-alumina + TZ-3Y samples packed in Na- $\beta$ "-alumina. The formation of Na- $\beta$ "-alumina was confirmed by XRD. Ionic conductivity of the converted samples was measured by EIS over a range of temperatures from $197^{\circ} \mathrm{C}$ to $485^{\circ} \mathrm{C}$. The measurement confirmed the formation of Fe-doped Na- $\beta$ "-alumina by the vapor phase process. The present work shows that by doping alumina with other cations, it should be possible to form two phase composites of doped Na- $\beta$ "-alumina + TZ-3Y by the vapor phase process. This opens up the possibility of manipulating transport properties of Na- $\beta$ "-alumina by various cation substitutions in the aluminum oxide lattice.

Acknowledgement: This work was supported by the National Science Foundation under Grant No. DMR-1407048. 


\section{References:}

1. Kummer, J.T., ' $\beta$-alumina electrolytes' p.141-175 in 'The Sodium-Sulfur Battery', edited by J. L. Sudworth and A. R. Tilley, Chapman and Hall, London (1985).

2. Peters, C.R., Bettman, M., Moore, J.W., Glick, M.D., 'Refinement of the structure of sodium $\beta$ alumina', Acta. Cryst., B27, 1826-1834 (1971).

3. L. L. Sudworth and A. R. Tilley, 'The Sodium-Sulfur Battery', Chapman and Hall, London (1985).

4. Dustmann, C.H., 'Advances in ZEBRA batteries', J. Power Sources, 127 (1-2) 85-92 (2004).

5. G. E. Youngblood, A. V. Virkar, W. R. Cannon and R. S. Gordon, Bull. Am. Ceram. Soc., 56206 (1977).

6. Virkar, A.V., Jue, J.F., Fung, K.Z., 'Alkali metal beta and beta" alumina and gallate polycrystalline ceramics and fabrication by a vapor phase process', US Patent No. 6,117,807. September 12, 2000.

7. Parthasarathy, P., Virkar, A.V., 'Vapor phase conversion of $\alpha$-alumina + zirconia composites into sodium ion conducting Na- $\beta$ "-alumina + zirconia solid electrolytes', J. Electrochem. Soc., 160 (11) A2268-A2280 (2013).

8. Phase Diagrams for Ceramists, Volume II. E. M. Levin, C. R. Robbins and H. F. McMurdie, The American Ceramic Society, Columbus, OH (1969). 
9. Muan, A., Gee, C.L., 'Phase Equilibrium Studies in the System Iron Oxide- $\mathrm{Al}_{2} \mathrm{O}_{3}$ in Air and at 1 Atm. $\mathrm{O}_{2}$ Pressure', J. Am. Ceram. Soc., 39 (6) 207-214 (1956).

10. L. Zhang, F. Liu, K. Brinkman, K. L. Reifsnider and A. V. Virkar, 'A study of gadolinia-doped ceria electrolyte by electrochemical impedance spectroscopy', J. Power Sources, 247 947-960 (2014).

11. S. P. S. Badwal, F. T. Ciacchi, K. M. Giampietro, 'Analysis of the conductivity of commercial easy sintering grade 3 mol. $\% \mathrm{Y}_{2} \mathrm{O}_{3}-\mathrm{ZrO}_{2}$ materials', Solid State Ionics, 176 169-178 (2005).

12. Virkar, A.V., Miller, G.R., Gordon, R.S., 'Resistivity-Microstructure Relations in Lithia-Stabilized Polycrystalline $\beta$ "-Alumina', J. Am. Ceram. Soc., 61 (5-6) 250-252 (1978). 
Table 1: Lattice Parameters

XRD Vegard's Law

\begin{tabular}{|l|l|l|l|l|l|l|}
\hline Sample & $\mathrm{a}(\AA)$ & $\mathrm{b}(\AA)$ & $\mathrm{c}(\AA)$ & $\mathrm{a}(\AA)$ & $\mathrm{b}(\AA)$ & $\mathrm{c}(\AA)$ \\
\hline $\begin{array}{l}\alpha-\mathrm{Al}_{2} \mathrm{O}_{3}+\mathrm{TZ}-3 \mathrm{Y} \\
\text { As-sintered }\end{array}$ & 4.747 & 4.747 & 12.967 & 4.747 & 4.747 & 12.967 \\
\hline $\begin{array}{l}\text { Fe-doped } \alpha-\mathrm{Al}_{2} \mathrm{O}_{3} \\
+\mathrm{TZ}-3 \mathrm{Y}\end{array}$ & 4.767 & 4.767 & 13.014 & 4.7806 & 4.7806 & 13.0519 \\
As- sintered & & & & & & \\
\hline $\begin{array}{l}\text { Fe-doped Na- } \beta "- \\
\text { alumina + TZ-3Y }\end{array}$ & 5.606 & 5.606 & 33.737 & & & \\
\hline
\end{tabular}

Table 2: Comparison of weight percentages of the various phases in different samples

\begin{tabular}{|l|l|l|l|l|}
\hline Sample/Weight Percentage & $\alpha-\mathrm{Al}_{2} \mathrm{O}_{3}$ & TZ-3Y & Na- $\beta$ "-alumina & wRp \\
\hline$\alpha-\mathrm{Al}_{2} \mathrm{O}_{3}+\mathrm{TZ}-3 \mathrm{Y}$ As-sintered & 64 & 36 & & \\
\hline Na- $\beta$ "-alumina $+\mathrm{TZ}-3 \mathrm{Y}$ & & 33.8 & 66.2 & \\
\hline Fe-doped $\alpha-\mathrm{Al}_{2} \mathrm{O}_{3}+\mathrm{TZ}-3 \mathrm{Y}$ & 62 & 38 & & \\
\hline Fe-doped Na- $\beta$ "-alumina + TZ-3Y & & 34 & 66 & \\
\hline
\end{tabular}

The above calculations assume all $\alpha$-alumina was converted into Na- $\beta$ "-alumina. However, there was some $\alpha$-alumina (non-contiguous) still left in the converted sample. 

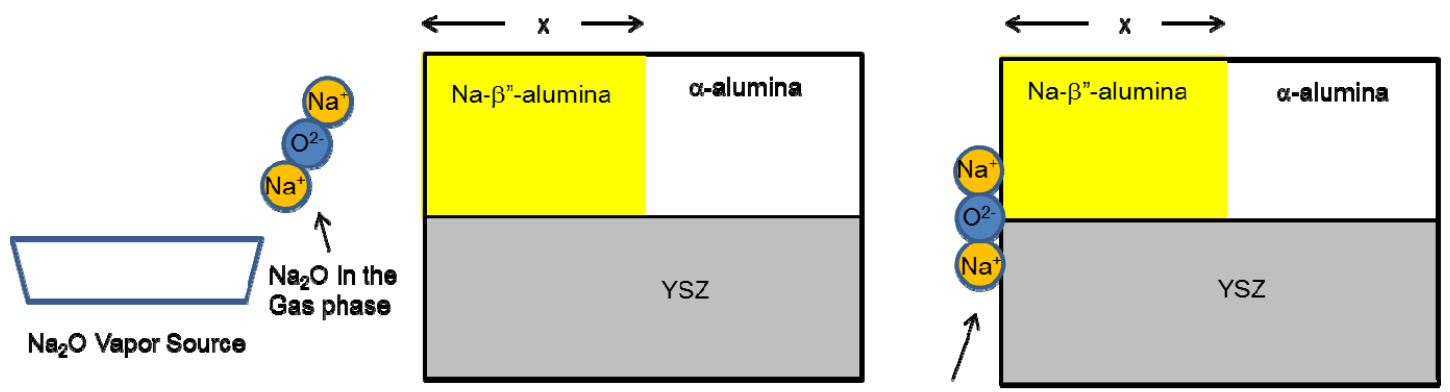

(a)

$\mathrm{Na}_{2} \mathrm{O}$ adsorbed

On the surface

(b)

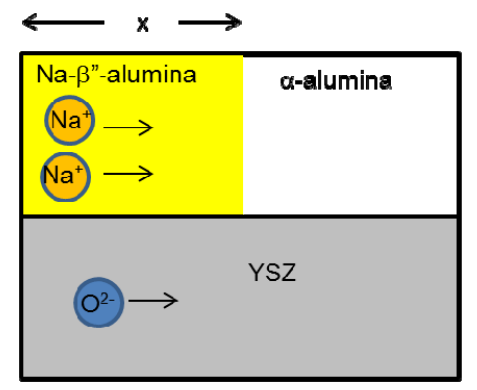

(c)

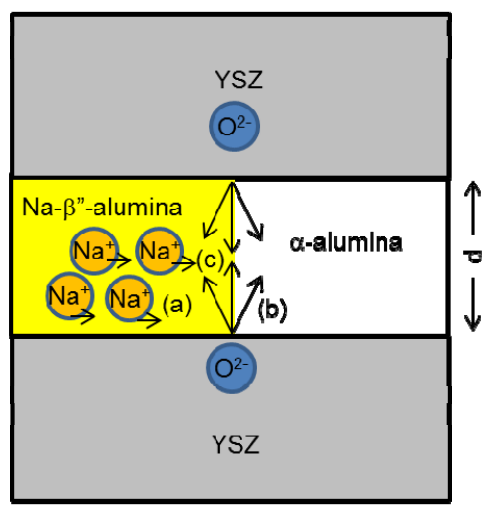

(d)

Figure 1: A schematic of a conceptual vapor phase process for the conversion of $\alpha$-alumina + YSZ into Na- $\beta$ "-alumina + YSZ. (a) $\mathrm{Na}_{2} \mathrm{O}$ molecule in the gas phase. (b) $\mathrm{Na}_{2} \mathrm{O}$ molecule adsorbed on the surface of Na- $\beta$ "-alumina + YSZ. (c) Coupled transport of $2 \mathrm{Na}^{+}$through $\mathrm{Na}-\beta$ "alumina and $\mathrm{O}^{2-}$ through YSZ. Reaction $2 \mathrm{Na}^{+}+\mathrm{O}^{2-}+\sim 6.0 \mathrm{Al}_{2} \mathrm{O}_{3} \rightarrow \mathrm{Na}_{2} \mathrm{O} \sim \sim 6.0 \mathrm{Al}_{2} \mathrm{O}_{3}(\beta ")$ occurs at the interface $\alpha$-alumina + YSZ/Na- $\beta$ "-alumina + YSZ. (d) Transport of oxygen at the reaction interface [7]. 


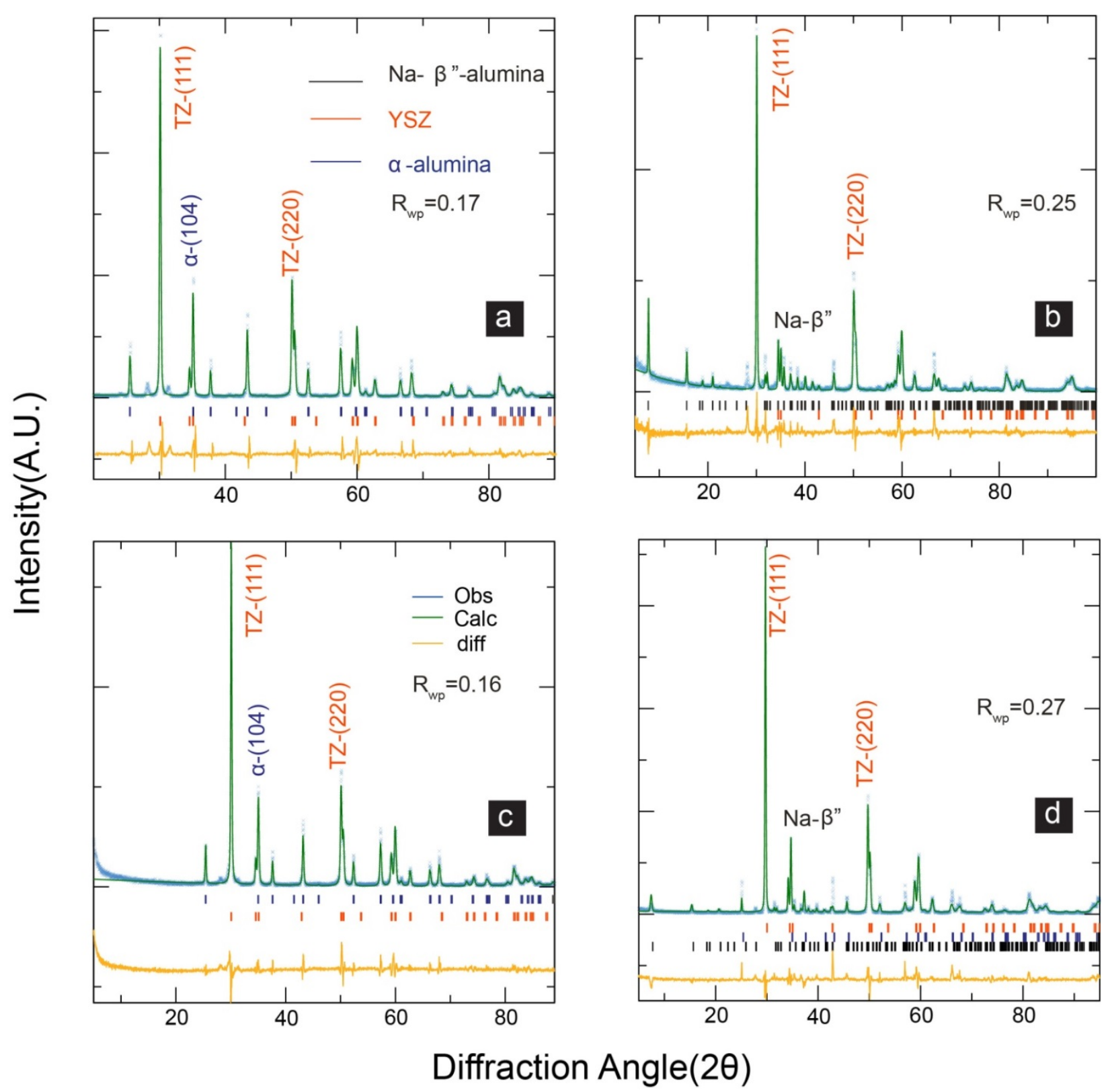

Figure 2: X-ray diffraction patterns of (a) As-sintered $\alpha-\mathrm{Al}_{2} \mathrm{O}_{3}+\mathrm{TZ}-3 \mathrm{Y}$, (b) After conversion to Na- $\beta$ "-alumina + TZ-3Y, (c) As-sintered Fe-doped $\alpha-\mathrm{Al}_{2} \mathrm{O}_{3}+$ TZ-3Y and (d) After conversion to Fe-doped Na- $\beta$ "-alumina + TZ-3Y. 


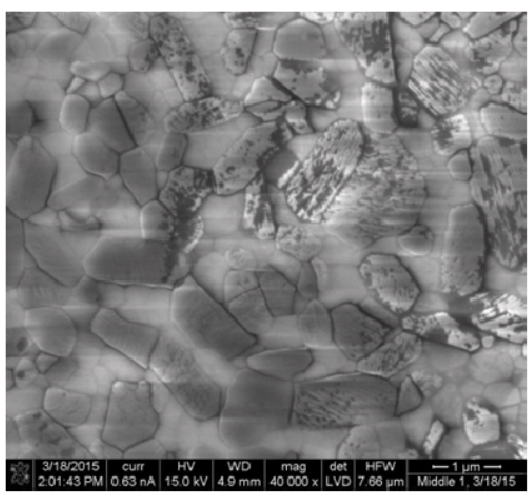

(a)

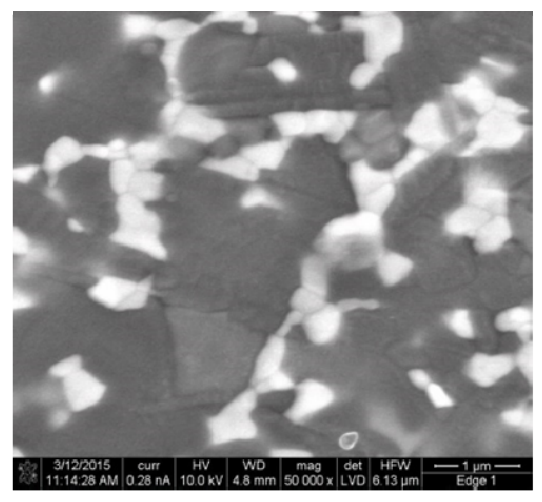

(b)

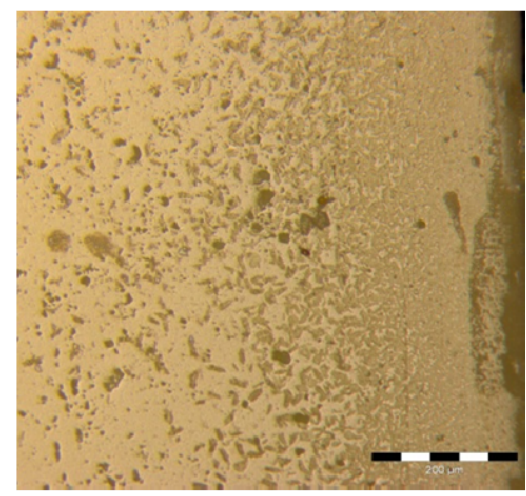

(c)

Figure 3: (a) An SEM micrograph of Fe-doped $\alpha-\mathrm{Al}_{2} \mathrm{O}_{3}+\mathrm{TZ}-3 \mathrm{Y}$, (b) An SEM image of the sample after conversion to Fe-doped Na- $\beta$ "-alumina + TZ-3Y (c) An optical micrograph showing the boundary between the converted and the unconverted sample. 

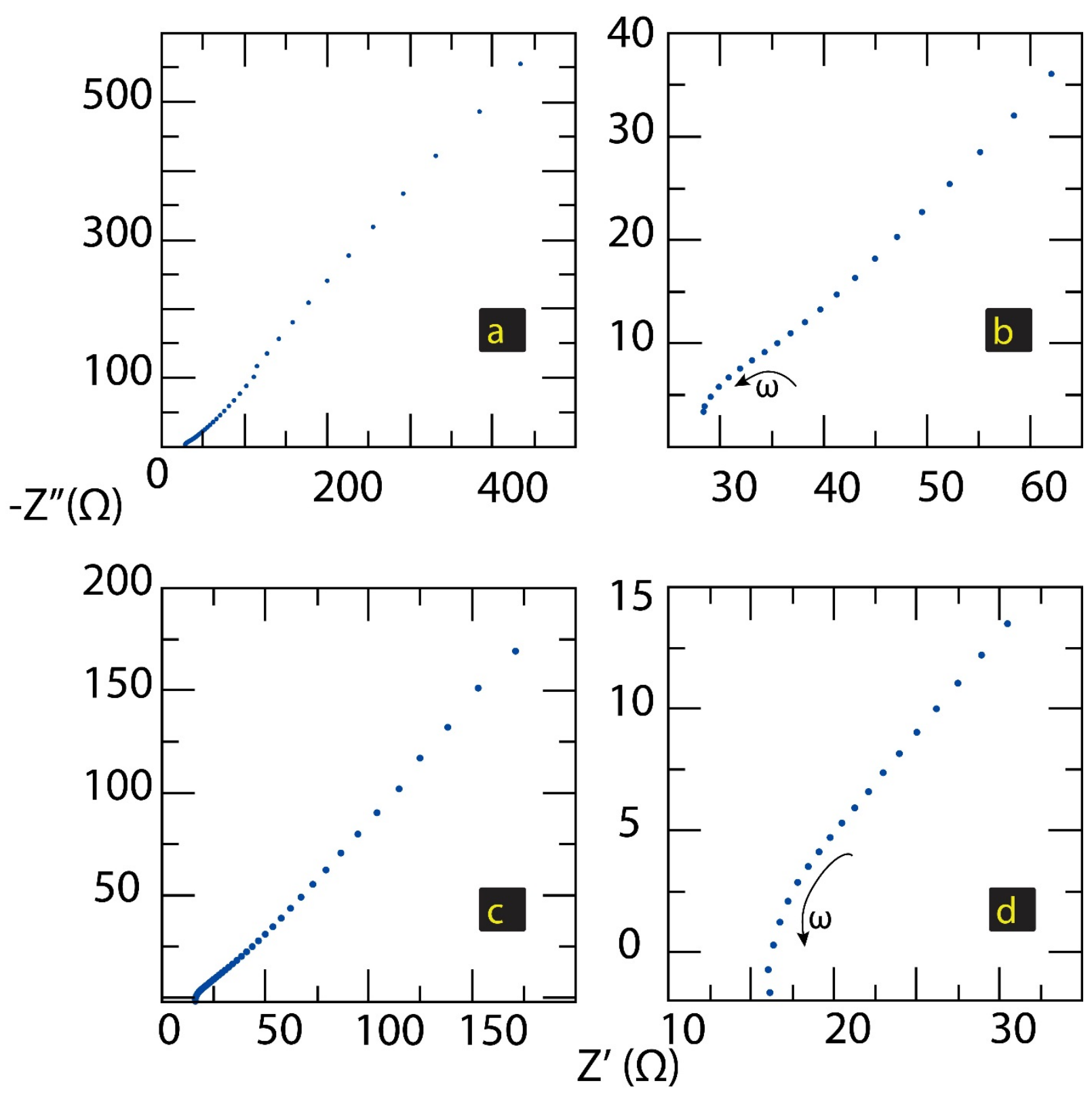

Figure 4: Electrochemical impedance spectra of the fully converted sample (a) at $197^{\circ} \mathrm{C}$ over the entire frequency range tested, (b) the high frequency regime at $197^{\circ} \mathrm{C}$, (c) at $290^{\circ} \mathrm{C}$ over the entire frequency range tested, (d) the high frequency regime at $290^{\circ} \mathrm{C}$. The arrows indicate the direction of increasing angular frequency, $\omega$. 


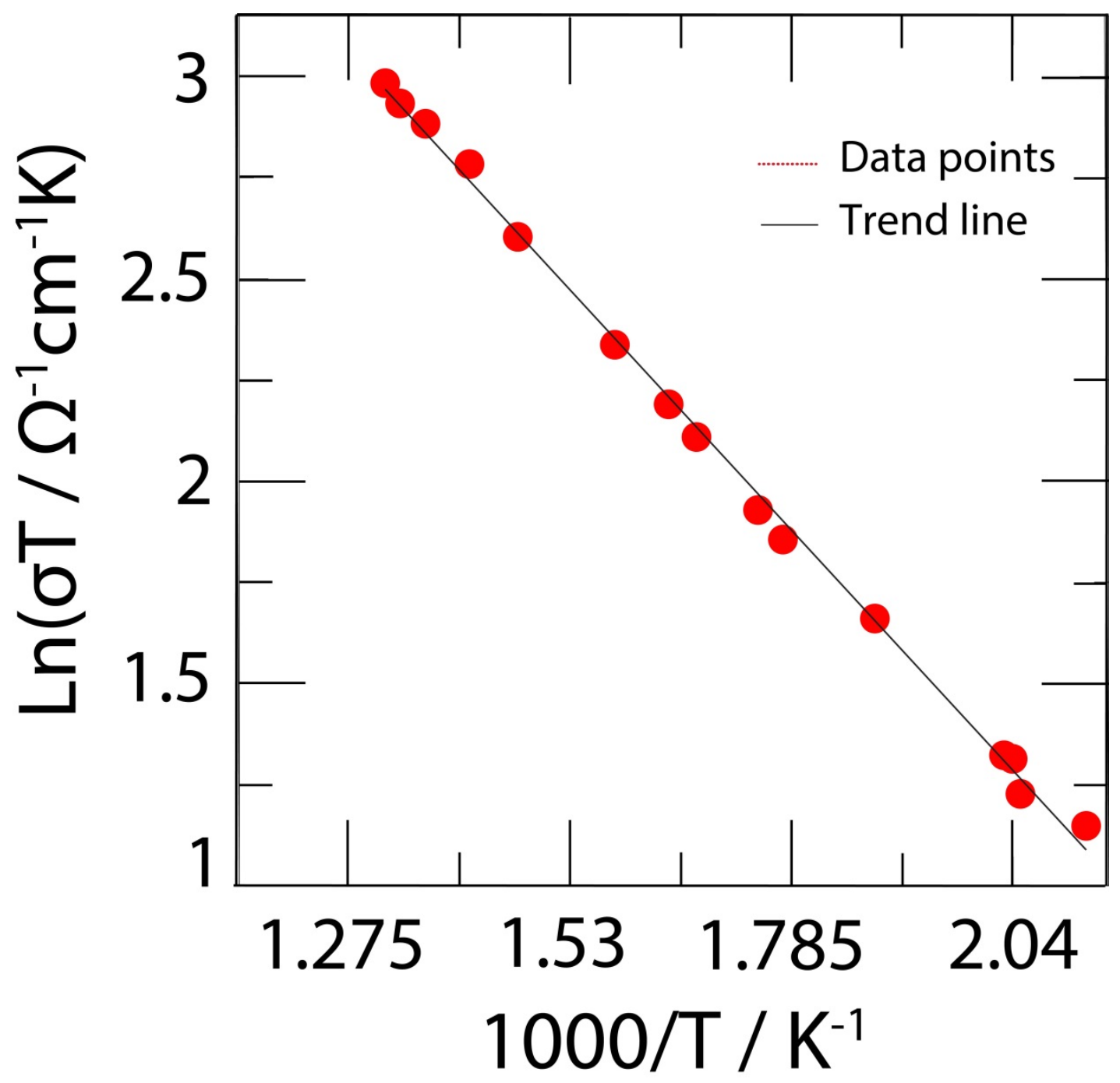

Figure 5: Arrhenius plot of the fully converted sample. 